\title{
Heparin, free fatty acids and an increased metabolic demand for oxygen
}

\author{
R. T. JUNG \\ M.B., M.R.C.P. \\ P. S. SHETTY \\ M.D. \\ W. P. T. JAMES \\ M.D., F.R.C.P. \\ MRC Dunn Clinical Nutrition Centre, Addenbrooke's Hospital, Cambridge
}

\begin{abstract}
Summary
Obese and lean subjects were given heparin with or without Intralipid in order to assess the effect of heparin on plasma concentration of free fatty acids (FFA) and oxidative metabolism. The FFA response depended on the triglyceride concentration and was associated with a prompt rise in oxygen consumption. Plasma catecholamines did not alter after heparin and the increase in oxygen uptake was proportional to the rise in FFA. The use of heparin, therefore, has metabolic disadvantages which may outweigh the potential benefits, for example in the management of myocardial infarction where heparin may increase the metabolic demand on the heart by increasing FFA levels.
\end{abstract}

\section{Introduction}

Heparin is used not only for the treatment of pulmonary emboli but often as an adjunct to the management of myocardial infarction. However, heparin has a potent metabolic effect in addition to its antithrombotic action: it is known to activate lipoprotein lipase (Connor and Armstrong, 1961) which will release free fatty acids (FFA) from both stored and circulating triglyceride (TG). The heparininduced rise in plasma FFA may increase the metabolic rate and this in turn may increase the demand for oxygen by the body's tissues. This could be detrimental in conditions such as myocardial infarction where a reduction in tissue oxygen demand is a major clinical objective.

The authors investigated the metabolic responsiveness of obese and lean subjects to changes in FFA induced by the injection or infusion of heparin in doses similar to those used clinically. The results show an appreciable increase in the body's demand for oxygen after heparin and these observations may, therefore, have clinical relevance.

Reprint requests and correspondence to: $\mathrm{Dr}$ R. T. Jung, Dunn Clinical Nutrition Centre, Addenbrooke's Hospital, Trumpington Street, Cambridge CB2 1QE.
Patients and methods

Eight obese and 6 lean subjects were investigatecis on an out-patient basis. All were normotensive and euthyroid women. These obese women were aged $43.6 \pm 5.0$ years (mean \pm s.e. mean) and weighed $100 \cdot 5 \pm 5.4 \mathrm{~kg}$, i.e. on average $80 \%$ above the ideaP body weight (IBW). The lean women were of similar $\vec{z}$ age (46.3 \pm 6.4 years) and weighed $49 \cdot 2 \pm 1.5 \mathrm{~kg}$, i.e $11 \%$ below IBW. IBW was defined as that corresponding to the midpoint of the weight range medium frame size as listed in the weight for heighte tables of the Metropolitan Insurance Company (1966)

The resting oxygen consumption $\left(\mathrm{RO}_{2}\right)$ and $\mathrm{C} \overline{\mathrm{e}}, \sum_{2}$ output were monitored at one-min intervals by the ventilated hood technique, after the subjects hack fasted for $12 \mathrm{hr}$ and rested supine for $30 \mathrm{~min}$. The oxygen consumption per min was expressed in equivalent units of heat production, i.e. in $\mathrm{kJ} / \mathrm{min}$.

After a preliminary measurement of $R \mathrm{O}_{2}$ for $30 \mathrm{~min}, 6$ of the subjects, 3 normal weight and $3 \overline{0}$ obese, were given a bolus of 5000 i.u. heparin i.v. and the change in oxygen consumption monitored at one -3 . min intervals for a further $2 \mathrm{hr}$. To induce greatero rises in plasma FFA concentrations, the remaining subjects were infused i.v. with variable amountso $\left(50\right.$ to $300 \mathrm{ml}$ ) of Intralipid $10 \%$ (Vitrum $\left.{ }^{\circledR}\right)$, and ${ }^{\circledR}$ were given an i.v. bolus of 5000 i.u. heparin. Toᄋ measure the effect of triglyceride infusion alone on $>$ oxygen consumption, 3 subjects were also infused을. with $10 \%$ Intralipid at $2.5 \mathrm{ml} / \mathrm{min}$ for one $\mathrm{hr}$.

Venous blood was taken from the other brachial ${ }^{\circ}$ vein with an Abbott $19 \mathrm{~g}$ Butterfly cannula, a few $N$ $\mathrm{ml}$ of sodium citrate BPC being used to keep the cannula patent. Blood for the estimation of plasmao FFA was transferred to ice-cold tubes containingo $\mathrm{Na}$ EDTA, the plasma FFA being measured by titration (Trout, Estes and Friedberg, 1960). Tri- $-?$ glyceride was measured with a Boehringer-Mannheim 0 enzymatic system (No. 125032). Blood for catechol-o amines was also obtained from 5 lean and 5 obese 


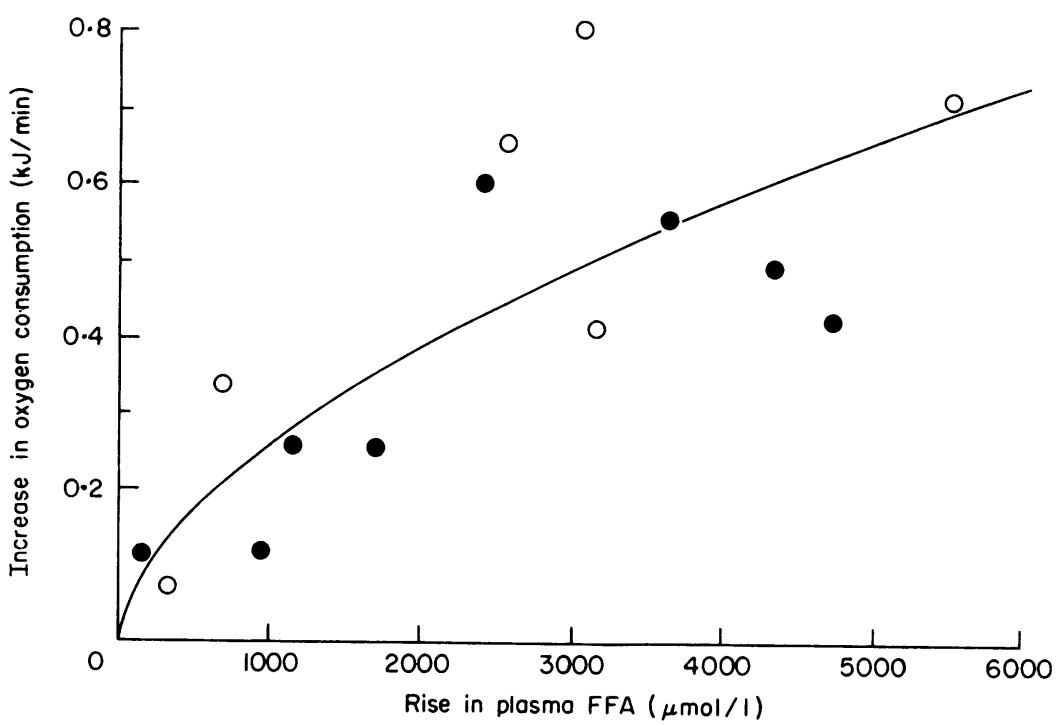

FIG. 1. The relationship between the maximum rise in oxygen consumption expressed in $\mathrm{kJ} / \mathrm{min}$ and the absolute increase in plasma free fatty acids $(\mu \mathrm{mol} / 1) 30 \mathrm{~min}$ after heparin injection $(r=0.84)$. The geometric regression line for both the obese and lean subjects is shown $\left(y=0.0047 x^{0.58}\right)$. $O=$ obese subjects; $O=$ lean subjects.

subjects before and $30 \mathrm{~min}$ after the heparin injection. The plasma catecholamines were measured by a radioenzymatic technique (Callingham and Barrand, 1979). Ethical approval and fully informed consent was obtained.

\section{Results}

The infusion of Intralipid alone raised the plasma triglyceride concentration from $0 \cdot 80 \pm 0.37$ to $2 \cdot 12 \pm$ $0.99 \mathrm{mmol} / \mathrm{l}$. Oxygen consumption showed no significant change $(4.65 \pm 0.33 \mathrm{~kJ} / \mathrm{min}$ before and $4.73 \pm$ $0.46 \mathrm{~kJ} / \mathrm{min}$ after one $\mathrm{hr}$ of Intralipid infusion).

On injecting heparin, however, the resting oxygen consumption increased promptly to reach a plateau at $30 \mathrm{~min}$. The peak rise in oxygen consumption was correlated with the increase in plasma FFA at 30 min, i.e. when there was a plateau in oxygen consumption. For the 14 subjects, this relationship (Fig. 1) was curvilinear $(r=0.84 ; P<0.001)$ and the equation which best fitted was as follows: $y=$ $0.0047 \times x^{0.58}$ where $y=$ rise in oxygen consumption in $\mathrm{kJ} / \mathrm{min}$ and $x=$ rise in plasma FFA in mmol/l. Both lean and obese groups separately showed a significant relationship $(r=0.89, P<0.02 ; r=0.84$, $P<0.01$ respectively) but there was no significant difference in their responses. In those given heparin alone after a 12-hr fast the FFA response related to the initial triglyceride level $(r=0.85, P<0.05)$ and resulted in a rise in oxygen consumption by as much as $0.34 \mathrm{~kJ} / \mathrm{min}$. In both the lean and obese groups, heparin did not alter either plasma noradrenaline (Table 1) or adrenaline.

TABLE 1. The plasma catecholamine concentrations before and after heparin

\begin{tabular}{lcccccc}
\hline & \multicolumn{2}{c}{ Lean (5) } & & \multicolumn{2}{c}{ Obese (5) } \\
\cline { 2 - 3 } \cline { 5 - 6 } & Before & After & & Before & After \\
\hline $\begin{array}{l}\text { Plasma noradrenaline } \\
\text { (nmol/l) }\end{array}$ & 2.50 & 2.18 & & 2.04 & 1.71 \\
& \pm & \pm & & \pm & \pm \\
& 0.47 & 0.54 & & 0.32 & 0.49 \\
$\begin{array}{l}\text { Plasma adrenaline } \\
\text { (nmol/l) }\end{array}$ & 0.13 & 0.13 & & 0.05 & 0.04 \\
& \pm & \pm & & \pm & \pm \\
& 0.03 & 0.04 & & 0.02 & 0.01 \\
\hline
\end{tabular}

Subject numbers in parentheses (mean \pm s.e. mean).

Conversion: SI to traditional units-plasma noradrenaline $1 \mathrm{nmol} / \mathrm{l} \equiv 0.17 \mathrm{ng} / \mathrm{ml}$; plasma adrenaline $1 \mathrm{nmol} / 1 \equiv 0.73$ $\mathrm{ng} / \mathrm{ml}$.

\section{Discussion}

The suggestion that heparin induces an increase in metabolic rate by increasing circulating FFAs is consistent with the recognition that FFAs stimulate the metabolism of in vitro preparations of both liver (Krebs, 1972) and renal cortex (Lee, Vance and Cahill, 1962). Although other mechanisms relating to catecholamine release could have been responsible for the metabolic response in the present subjects, no appreciable change in either hormone was found 
after i.v. heparin, so a direct thermogenic stimulus to metabolism by these hormones is unlikely. The increase in oxygen consumption after heparin was related to the rise in FFA in curvilinear fashion, this relationship becoming more linear when the rise in plasma FFA was more than $1000 \mu \mathrm{mol} / 1$. Previous isotopic work had demonstrated a linear relationship between the rate of FFA oxidation and the actual plasma FFA concentration but this was only shown over a $1000 \mu \mathrm{mol} / 1$ rise in FFA (Issekutz et al., 1968). A similar response in oxygen uptake to a rise in FFA was found in both lean and obese subjects (Issekutz et al., 1968), as confirmed by the present work. However, the obese may be expected to have a greater metabolic response to heparin because of the greater availability of circulating triglycerides.

The increase in plasma FFA seems to depend not only on the concentration of plasma triglyceride but also on the dose of heparin used and its route of administration. Heparin given subcutaneously at a dose of 5000 i.u. after a fatty meal will raise the plasma FFA up to $2000 \mu \mathrm{mol} / 1$ while 15000 i.u. given i.v. can produce an increase in plasma FFA to over $5000 \mu \mathrm{mol} / 1$ (Nordoy et al., 1977). Such an increase can be expected to increase the metabolic rate by $0.7 \mathrm{~kJ} / \mathrm{min}$ or $25 \%$. Although Connor and Armstrong (1961) showed that heparin (5000 i.u.) given as an i.v. bolus rather than as a subcutaneous dose, results in a greater initial rise of both plasma lipoprotein lipase and glycerol, the effects of the i.v. heparin lasted only $6 \mathrm{hr}$. In contrast, heparin given subcutaneously produced a persistent increase in the plasma lipoprotein lipase and glycerol for $24 \mathrm{hr}$.

These metabolic effects of heparin on plasma FFA concentrations and oxygen uptake may prove disadvantageous in several clinical conditions. In myocardial ischaemia, the development of infarction is a progressive process which can be modified by reducing myocardial oxygen requirements. Recently it has been shown that the oxygen consumption of the myocardium is increased by elevated FFA without an improvement in its mechanical function (Simonsen and Kjekshus, 1978). The present data suggest that the use of i.v. heparin not only increases the peripheral oxygen requirements in the fasted state but more so in the fed state: this would therefore lead to a demand for an increased cardiac output (Bevegård and Shepherd, 1967). If cardiac arrhythmias are induced by a high plasma FFA (Kurien and Oliver, 1970) then heparin may also complicate the management of patients with a myocardial infarct (Opie, Tansey and Kennelly, 1977). The FFA response to elevated plasma concentrations of adrenaline in patients with a myocardial infarct (Siggers, Salter and Fluck, 1971) can be blocked with a $\beta$-adrenergic blocking drug but this blockade would not limit the FFA response to heparin. Thus there is a need to balance the potential benefits accruing from diminished thrombotic function witk the metabolic disadvantages of heparin and it would certainly seem wise to limit the use of heparin ir. obese patients known to have hypertriglyceridaemia

A further use for heparin is in association with the parenteral feeding of lipid preparations. The authors $\frac{\mathrm{t}}{\mathrm{O}}$ observations show no effect of triglyceride infusior on the metabolic rate but the combination of botr Intralipid and heparin may be expected to produce $\mathbb{P}$ very large increase in plasma FFA. This could bê detrimental as suggested by the recent report of 5 deaths from myocardial infarction in heparinizedsubjects receiving Intralipid during haemodialysisw (Bergrem and Lievested, 1978).

\section{Acknowledgments}

We thank all our volunteers for their co-operationo Dr B. A. Callingham and Dr M. Barrand for measuring the plasma catecholamines and $\mathrm{Mr} \mathrm{T}$. J. Cole for statisticaU advice.

\section{References}

Bergrem, H. \& Leivestad, T. (1978) Dialysis death and increased free fatty acids. Lancet, ii, 1160.

BEVEGARD, B.S. \& SHEPHERD, J.T. (1967) Regulation of the circulation during exercise in man. Physiological Reviews,

47, 179.
Callingham, B.A. \& Barrand, M.A. (1979) In: Hormogeg in Blood. (Ed. by Gray, C.H. \& James, V.H.T.), 3rd ogn: Academic Press, London and New York (in press). ెㅡ.

Connor, W.E. \& ARmstrong, M.L. (1961) Plasma lizpo protein lipase after subcutaneous heparin. Circulation, 24 87.

Issekutz, B., Paul, P., Miller, H.I. \& Bortz, W.M. (1968足 Oxidation of plasma FFA in lean and obese humans Metabolism, 17, 62.

KREBS, H.A. (1972) Advances in Enzyme Regulation, Vol. $10 \stackrel{\overrightarrow{\mathrm{B}}}{\mathrm{B}}$ (Ed. by Weber, G.), p. 397. Pergamon Press, Oxford.

KURIEN, V.A. \& Oliver, M.F. (1970) A metabolic cause fo arrhythmias during acute myocardial ischaemia. Lancet $\bar{p}$. i, 813.

LEE, J.B., VANCE, V.K. \& CAHILl, G.F. (1962) Metabolism of $C^{14}$-labeled substrates by rabbit kidney cortex and medulla. American Journal of Physiology, 203, 27.

Metropolitan Life Insurance Company, New York (1960) Statistical Bulletin, 41, Feb. p. 6, March p. 7.

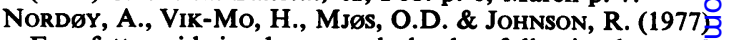
Free fatty acids in plasma and platelets following low an $\delta$ high-dose heparin during alimentary hyperlipaemia. Actळ medica scandinavica, 202, 163.

OpIE, L.H., TANSEy, M. \& KenNelly, B.M. (1977) Proposedp metabolic vicious circle in patients with large myocardiaf. infarcts and high plasma free fatty acid concentrations Lancet, ii, 890.

Siggers, D.C., SAlter, C. \& Fluck, D.C. (1971) Seriaf plasma adrenaline and noradrenaline levels in myocardia infarction using a new double isotope technique. British
Heart Journal, 33, 878.

Simonsen, S. \& KJEKSHUS, J.K. (1978) The effect of free fattse acids on myocardial oxygen consumption during a tria $\bar{D}$ pacing and catecholamine infusion in man. Circulation, 58? 484.

Trout, D.L., Estes, E.H. \& FriedberG, S.J. (1960) Titration of free fatty acids of plasma: a study of current methods and a new modification. Journal of Lipid Research, 1, 199 